\title{
REGIONALIZATION OF LOW-FLOW CHARACTERISTICS OF ARKANSAS STREAMS
}

By A.H. Ludwig and Gary D. Tasker

U.S. GEOLOGICAL SURVEY

Water-Resources Investigations Report 93-4013

Prepared in cooperation with the ARKANSAS SOIL AND WATER CONSERVATION COMMISSION 


\title{
U.S. DEPARTMENT OF THE INTERIOR BRUCE BABBITT, Secretary
}

\author{
U.S. GEOLOGICAL SURVEY
}

Dallas L. Peck, Director

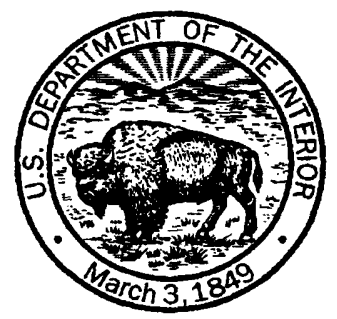

For additional information write to:

District Chief

U.S. Geological Survey

Water Resources Division

2301 Federal Office Building

Little Rock, Arkansas 72201
Copies of this report can be purchased from:

U.S. Geological Survey

Books and Open-File Reports Section

Federal Center, Building 810

Box 25425

Denver, Colorado 80225 


\section{CONTENTS}

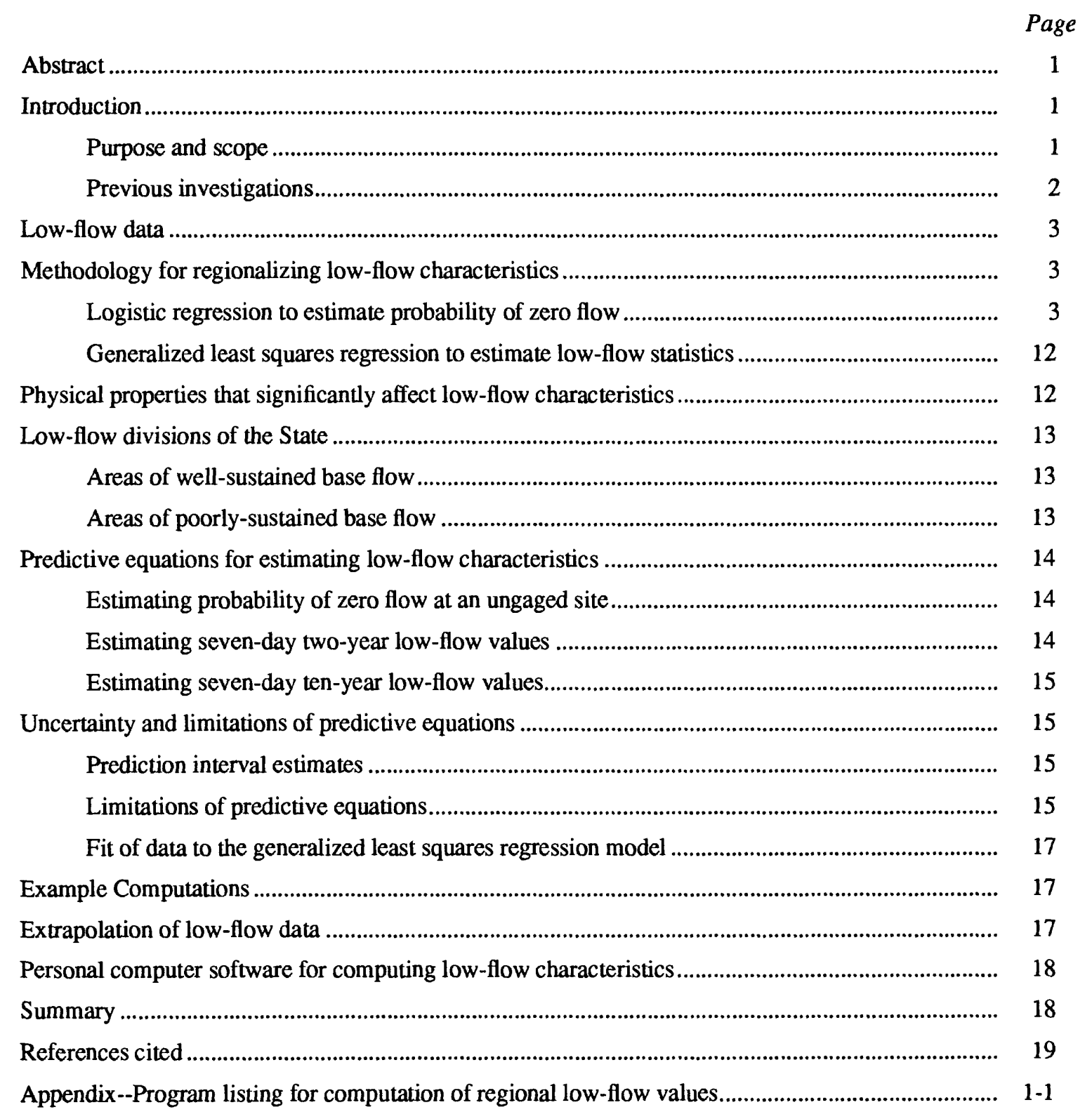

\section{ILLUSTRATIONS \\ [Plate is located in back pocket at end of report]}

Figure 1. Map showing location of study area and physiographic divisions........................................ 2

Plate 1. Map showing locations of gaging stations and low-flow regions of Arkansas

\section{TABLES}

Table 1. Hydrologic characteristics for surface-water gaging stations used in the regression analyses. 4

2. Values needed to calculate confidence intervals ............................................................... 16 


\section{CONVERSION FACTORS}

Multiply

cubic foot per second $\left(\mathrm{ft}^{3} / \mathrm{s}\right)$

mile (mi)

square mile $\left(\mathrm{mi}^{2}\right)$
By

0.02832

1.609

2.590
To obtain

cubic meter per second

kilometer

square kilometer

Note: Before running the ARK program please be sure that

the ANSI.SYS device line is in the CONFIG.SYS file.

The CONFIG.SYS file is located in the root directory of the c: drive.

To get to the correct location enter the following commands.

C:

$\mathrm{cd} 1$

To view the current CONFIG.SYS file enter following:

type CONFIG.SYS

The ANSI.SYS line should be SIMILAR to one of the following lines:

DEVICE $=$ ANSI.SYS

or

DEVICE $=C: \backslash$ ANS I .SYS

or

DEVICE $=C: \backslash D O S \backslash$ ANSI.$S Y S$

or

$D E V I C E=C: \backslash B I N \backslash A N S I$.SYS

If your current CONFIG.SYS file does not contain a line similar

to one of the lines listed above, find the location of ANSI.SYS

on your machine. Your local PC support person can help you

find it if you have problems.

Add a line to CONFIG.SYS that describes the location of

ANSI.SYS. Use a format similar to the above examples. 


\title{
REGIONALIZATION OF LOW-FLOW CHARACTERISTICS OF ARKANSAS STREAMS
}

\author{
by A.H. Ludwig and Gary D. Tasker
}

\begin{abstract}
Equations for estimating the 7-day 2-year and 7-day 10-year low flow at sites on ungaged streams are presented. Regression analysis was used to develop equations relating basin characteristics and low-flow characteristics at 58 continuous-record gaging stations and 151 partial-record sites. Significant basin characteristics in the equations are drainage area and percentage of drainage basin underlain by permeable bedrock units. The study area, which encompasses the western two-thirds of the State, is divided into three regions based on the similarity of basin characteristics within each region. The analysis includes records for only those stations that are not highly regulated and have drainage areas less than 1,000 square miles.

A three-step method is used to estimate low-flow characteristics at ungaged sites. The first step involves the use of a logistic regression to determine the probability that the 7-day annual minimum flow is zero at the site of interest. The second step uses this estimated probability of 7-day annual zero flow to determine if the estimated value of the 7 day 2-year or the 7-day 10-year low flow is zero or needs to be estimated from one of the regional equations, which are based on a generalized-least-squares model for sites with non-zero flow. The third step involves the use of the regional equation, if flow is indicated, to determine the 7-day 2-year and 10-year low-flow values.

Computer software has been written to facilitate the computation of low-flow characteristics at sites of interest. The software is provided in written form and on a disk.

\section{INTRODUCTION}

Knowledge of low-flow characteristics of Arkansas streams is important in water-resource planning, particularly when questions related to draft storage requirements, dilution of contaminants, navigation, and maintenance of fish and wildlife habitat are concerned. From data collected at continuous and partial-record gaging stations operated by the U.S. Geological Survey (USGS) and other Federal agencies, low-flow characteristics (for example, 7-day 2-year and 7-day 10-year low flows) have been computed (Ludwig, 1992) and are available for helping make water-resource management decisions at these sites. Low-flow characteristics are commonly needed at sites for which daily discharge records or miscellaneous discharge measurements do not exist. This report, a product of a study by the USGS, in cooperation with the Arkansas Soil and Water Conservation Commission, is the first to describe a method for the determination of low-flow characteristics at ungaged sites within the State of Arkansas.
\end{abstract}

\section{Purnose and Scope}

This report briefly describes the regression analysis techniques selected to effect the transfer of low-flow characteristics from gaged to ungaged stream sites, and provides the resulting predictive equations to estimate values of 7-day low flow for recurrence intervals of 2 and 10 years $\left(Q_{7,2}\right.$ and $\left.Q_{7,10}\right)$ at ungaged stream sites in the study area.

The study area includes the western two-thirds of the State (fig. 1). The eastern one-third of the State, which lies within the Mississippi Alluvial Plain, has been excluded from the study because withdrawals and return flows associated with irrigation throughout the area make the determination of predictable low-flow characteristics impossible. 


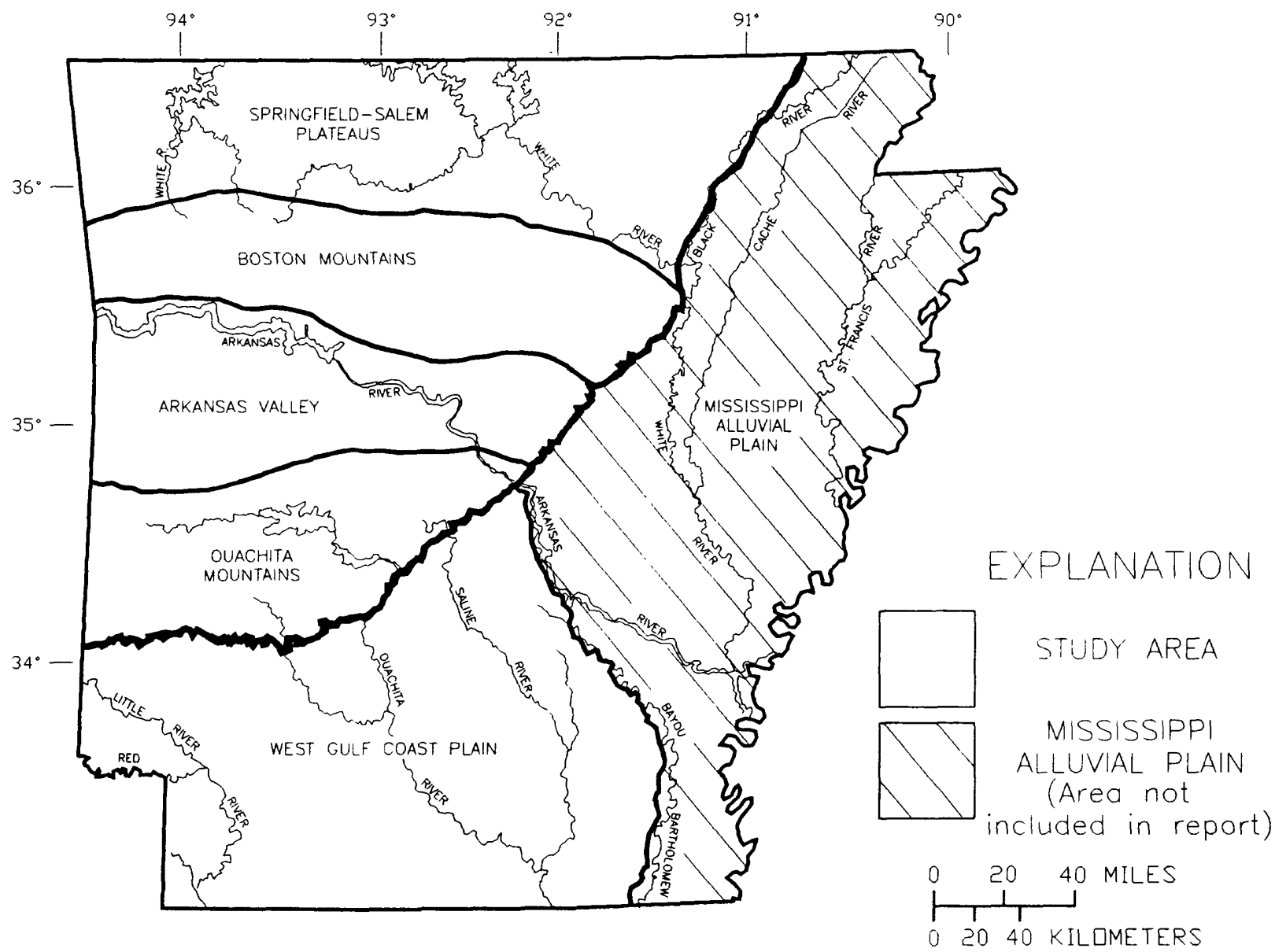

Figure 1.--Location of study area and physiographic divisions.

\section{Previous Investigations}

Four previous reports deal with statewide low-flow stream characteristics. The first report by Hines (1965) contained information on low-flow frequency and flow duration for unregulated sites. The second report (Hines, 1975) contained updated low-flow statistical information for regulated as well as unregulated sites. Hunrichs (1983) identified perennial streams in most areas of Arkansas based on a range of 7-day 10-year low-flow $\left(Q_{7,10}\right)$ discharges. The fourth report (Ludwig, 1992) is an update, based on additional period of record (1970-1990), of the information contained in the second report by Hines (1975).

This report is the first that has dealt with the regionalization of low-flow characteristics for Arkansas streams. The low-flow characteristics for gaged sites on Arkansas streams presented by Ludwig (1992) are the basis for the regionalization work documented in this report.

Techniques for determining the storage requirements of Arkansas streams are described in a report by Patterson (1968). Another report by Patterson (1971) contains information on the magnitude and frequency of floods in Arkansas through 1968. This work has also been updated through 1984 in a report by Neely (1987). These and other reports describing streamflow characteristics in Arkansas are listed in the references at the end of the report. 


\section{LOW-FLOW DATA}

The study is based on the analysis of daily discharge records from 58 continuous-record gaging stations, including 23 active and 35 discontinued stations, and from 151 partial-record sites. These data have been updated through the 1990 water year (Ludwig, 1992). Only those continuous-record gaging stations that have 10 or more years of streamflow record, that are not highly regulated, and have drainage areas less than $1,000 \mathrm{mi}^{2}$ were included in the analysis. Partial-record sites were limited to locations having six or more low-flow measurements.

Table 1 contains the list of stations and associated data upon which the regionalization analysis presented in this report is based. Included in table 1 are the values for $Q_{7,2}$ and $Q_{7,10}$ that have been determined at each site (Ludwig, 1992). Also included are the region and basin factor for each station. Region is a designation for a geographic area in which low flows may be estimated by a common equation. Regions are primarily defined on the basis of the permeability of the underlying bedrock. Basin factor defines the percentage of a given drainage basin underlain by permeable bedrock. The approximate location and type of each station is shown in plate 1 . The map number given in table 1 is the station reference number in plate 1 .

\section{METHODOLOGY FOR REGIONALIZING LOW-FLOW CHARACTERISTICS}

Two types of regression analysis were used in this study to regionalize low-flow characteristics based upon data observed at stream-gaging stations. Logistic regression was used to estimate the probability of an annual minimum flow being zero and generalized least squares regression was used to estimate $Q_{7,2}$ and $Q_{7,10}$. The independent variables in both models are basin characteristics. The theory behind each approach is discussed in the following two sections.

\section{Logistic Regression to Estimate Probability of Zero Flow}

At many streams in Arkansas the minimum flow for a year is zero. To estimate the probability of having a minimum of zero at an ungaged site, a regional logistic regression model that relates probability of a zero minimum flow at a site to physical, meteorological, and geological characteristics of the watershed can be developed (Tasker, 1989). Consider a collection of $p$ basin characteristics denoted by the vector $x^{\prime}=\left(x_{1}, x_{2} \ldots, x_{p}\right)$. Let $\pi(\mathbf{x})$ denote the probability that the annual minimum flow associated with a duration, such as 7-day, 30-day, or 90-day, is nonzero. The multiple logistic regression model may be described as follows:

where

$$
\pi(x)=\frac{e^{g(x)}}{1+e^{g(x)}}
$$

$$
g(x)=\beta_{o}+\beta_{1} x_{1}+\beta_{2} x_{2}+\ldots+\beta_{p} x_{p}
$$

Consequently, the probability that the annual minimum flow associated with a particular time duration is zero may be described as follows:

$$
1-\pi(x)=1-\frac{e^{g(x)}}{1+e^{g(x)}}
$$

By use of sample data collected at stream gages in the area (table 1), the unknown $\beta$ 's are estimated by maximizing the log likelihood function

$$
L(\beta)=\sum_{i=1}^{n}\left\{y_{i} \ln [\pi(x)]+\left(1-y_{i}\right) \ln [1-\pi(x)]\right\}
$$

in which $y_{i}=1$ if an observed annual minimum is nonzero in year $i$ and $y_{i}=0$ if an observed annual minimum is zero and $\mathrm{n}$ is the total number of observations at all sites. 


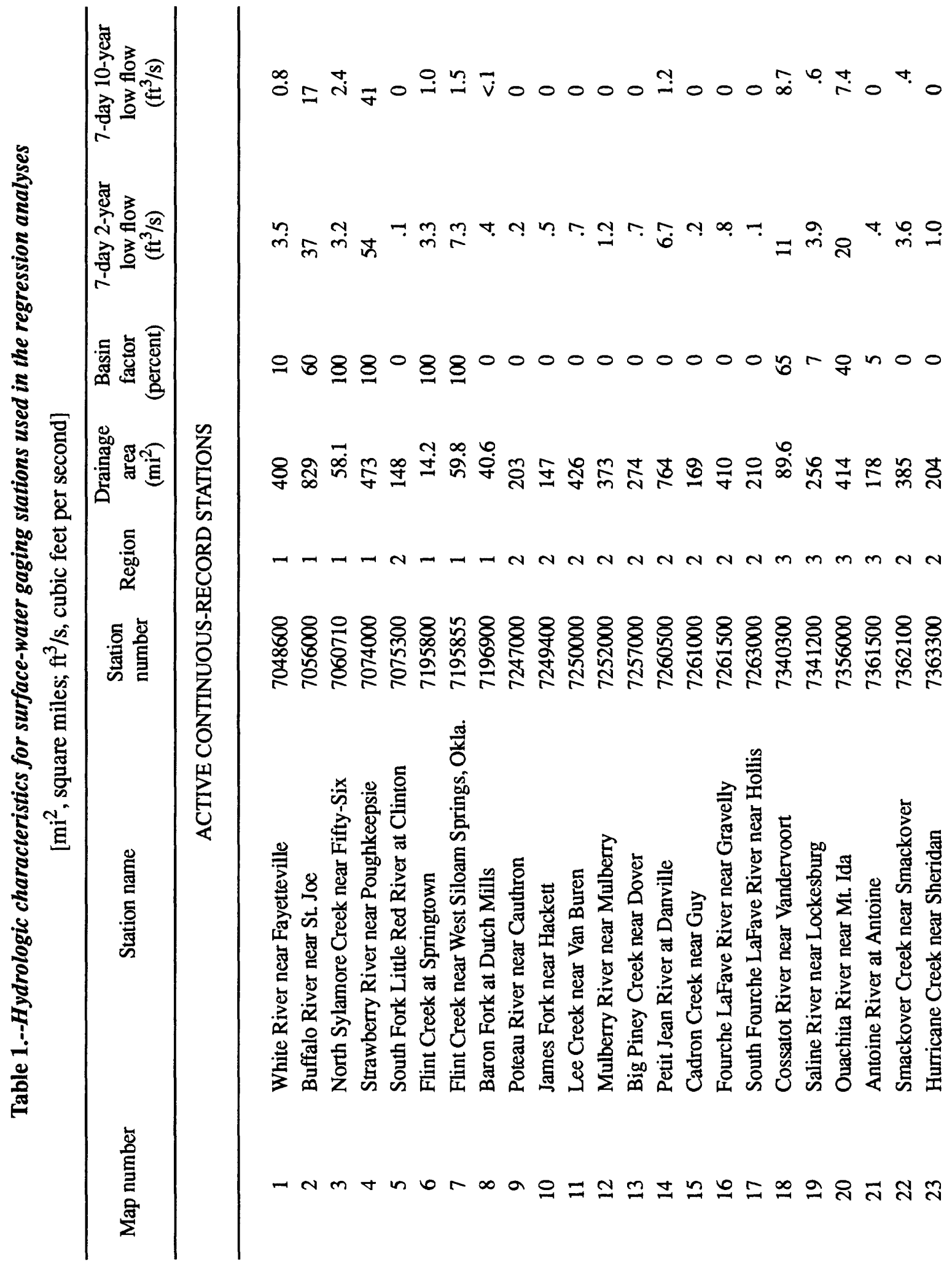




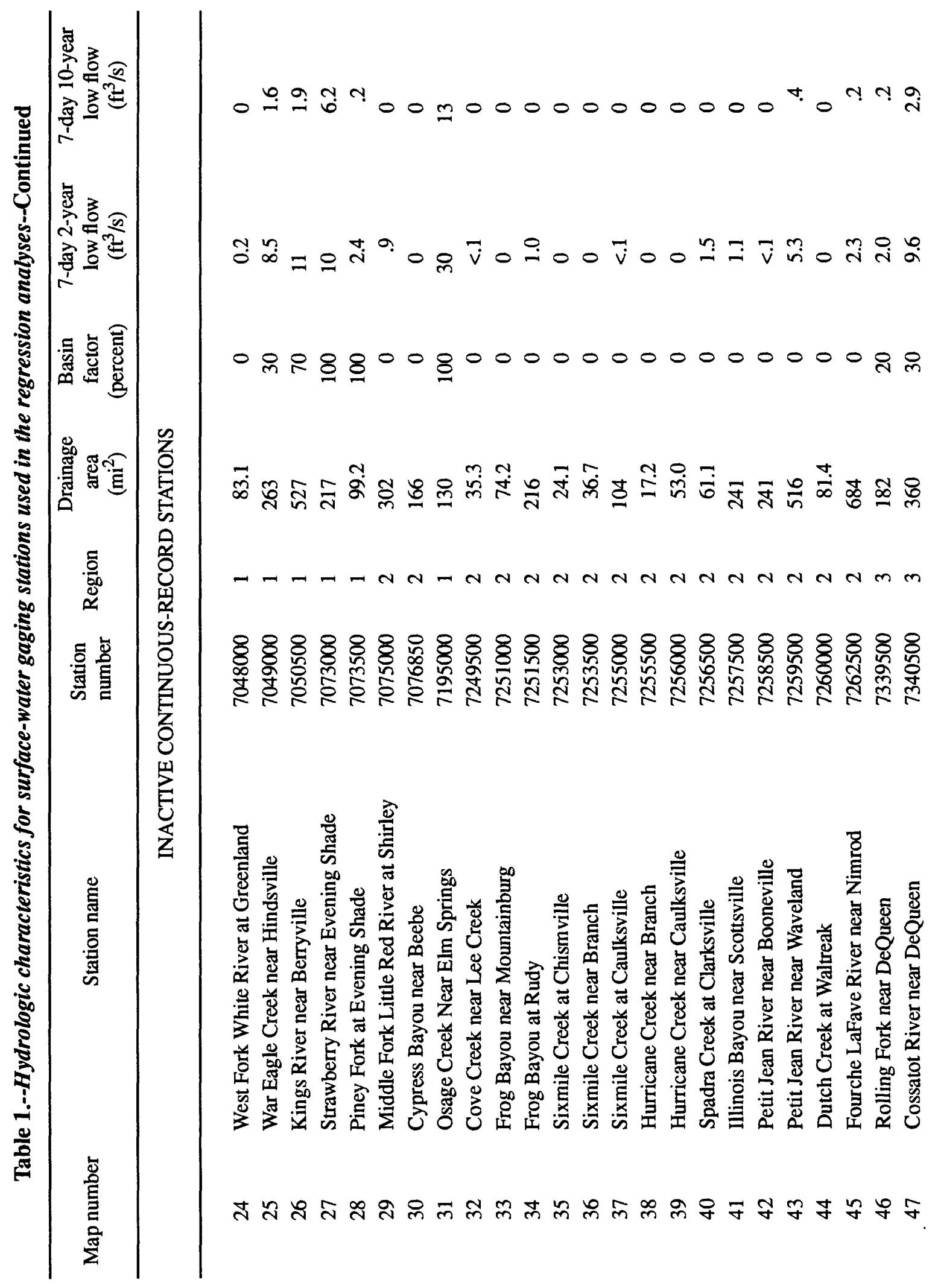




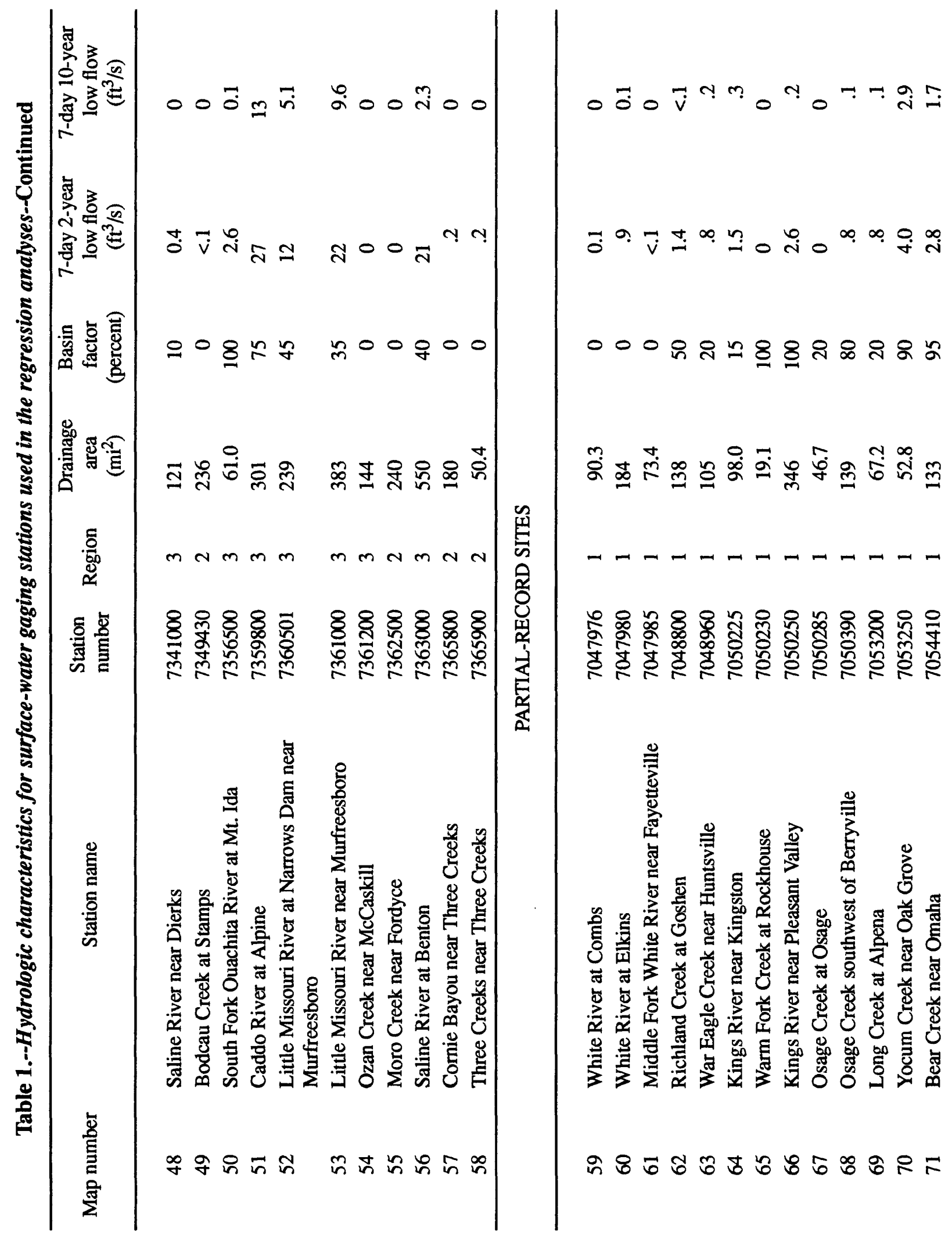




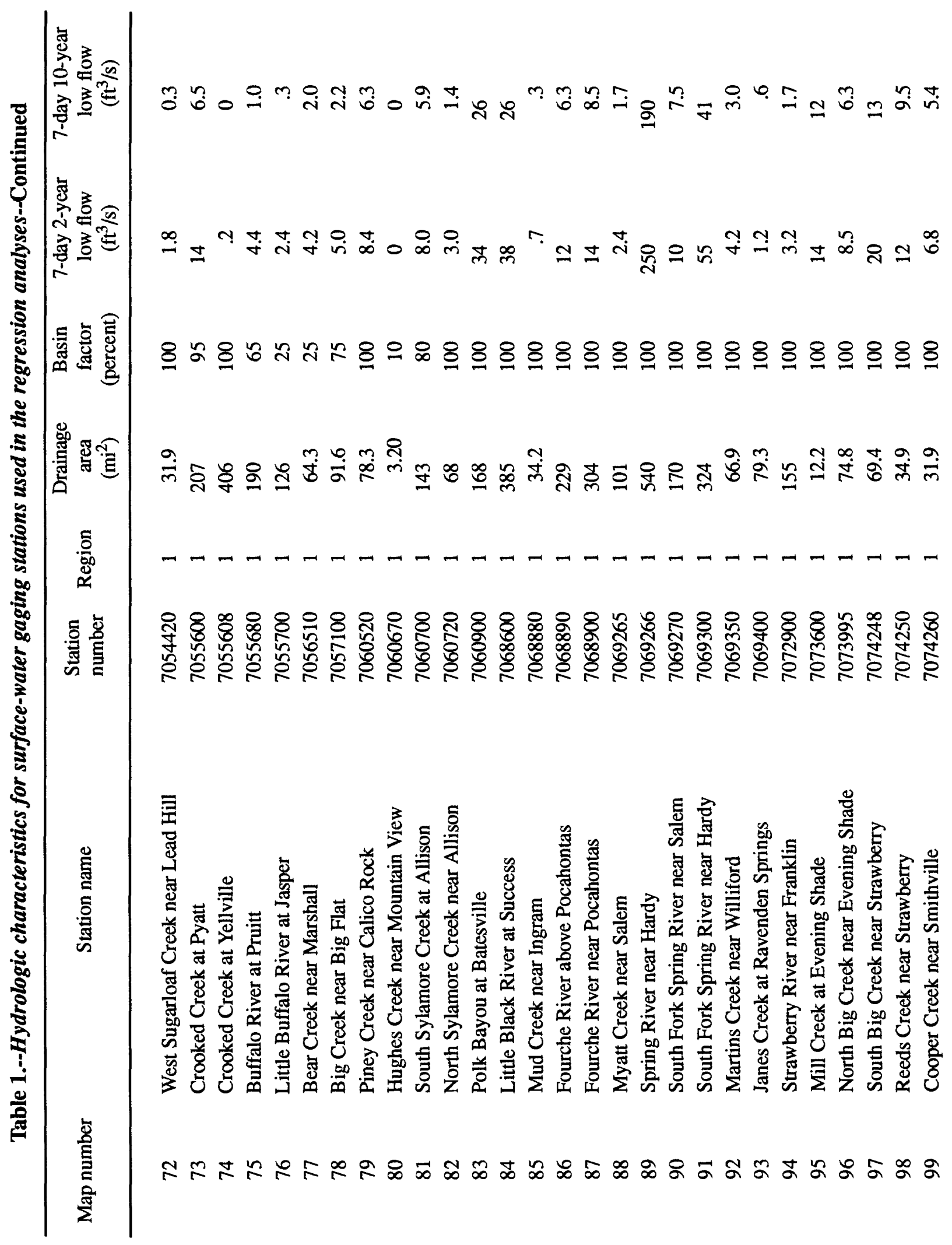




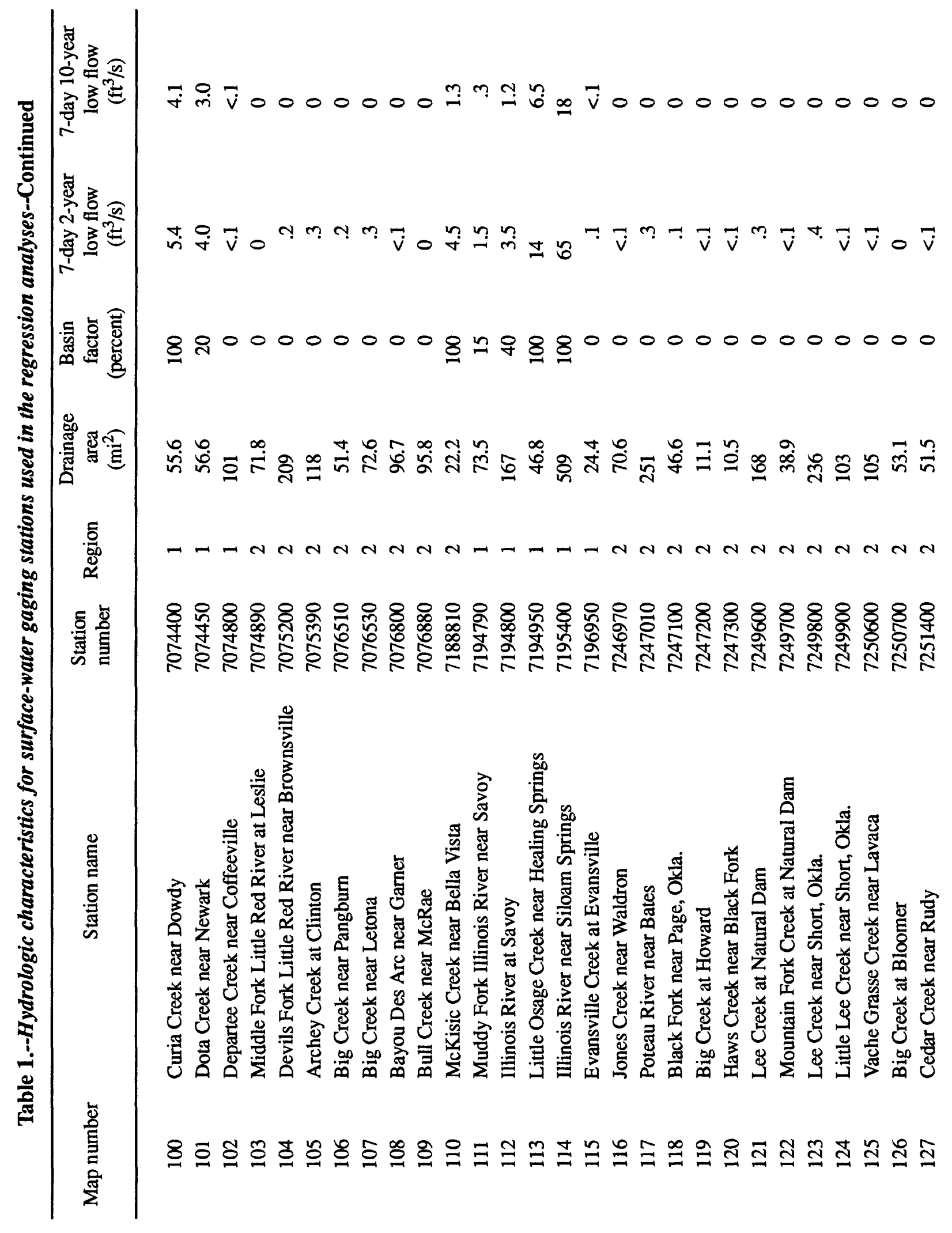




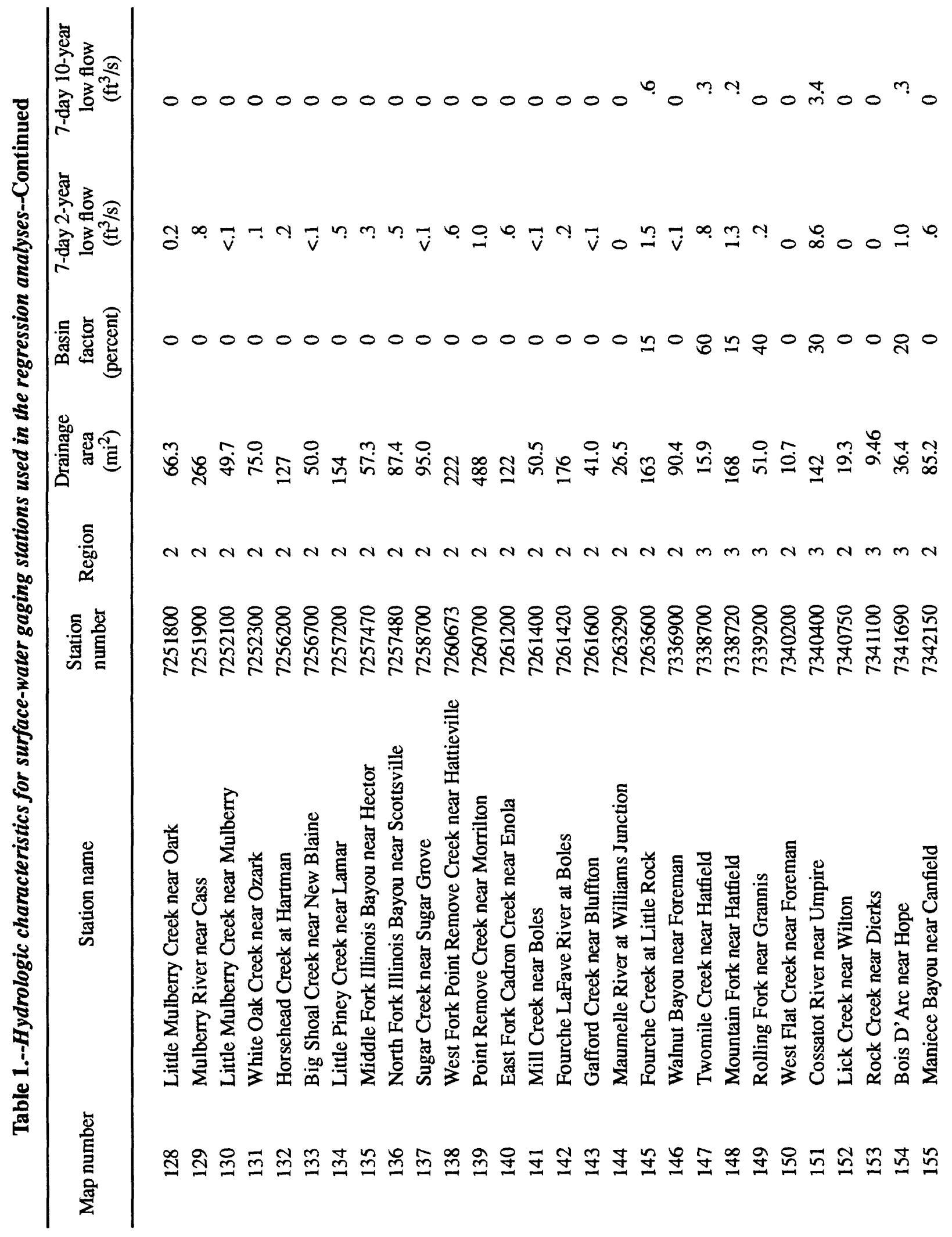




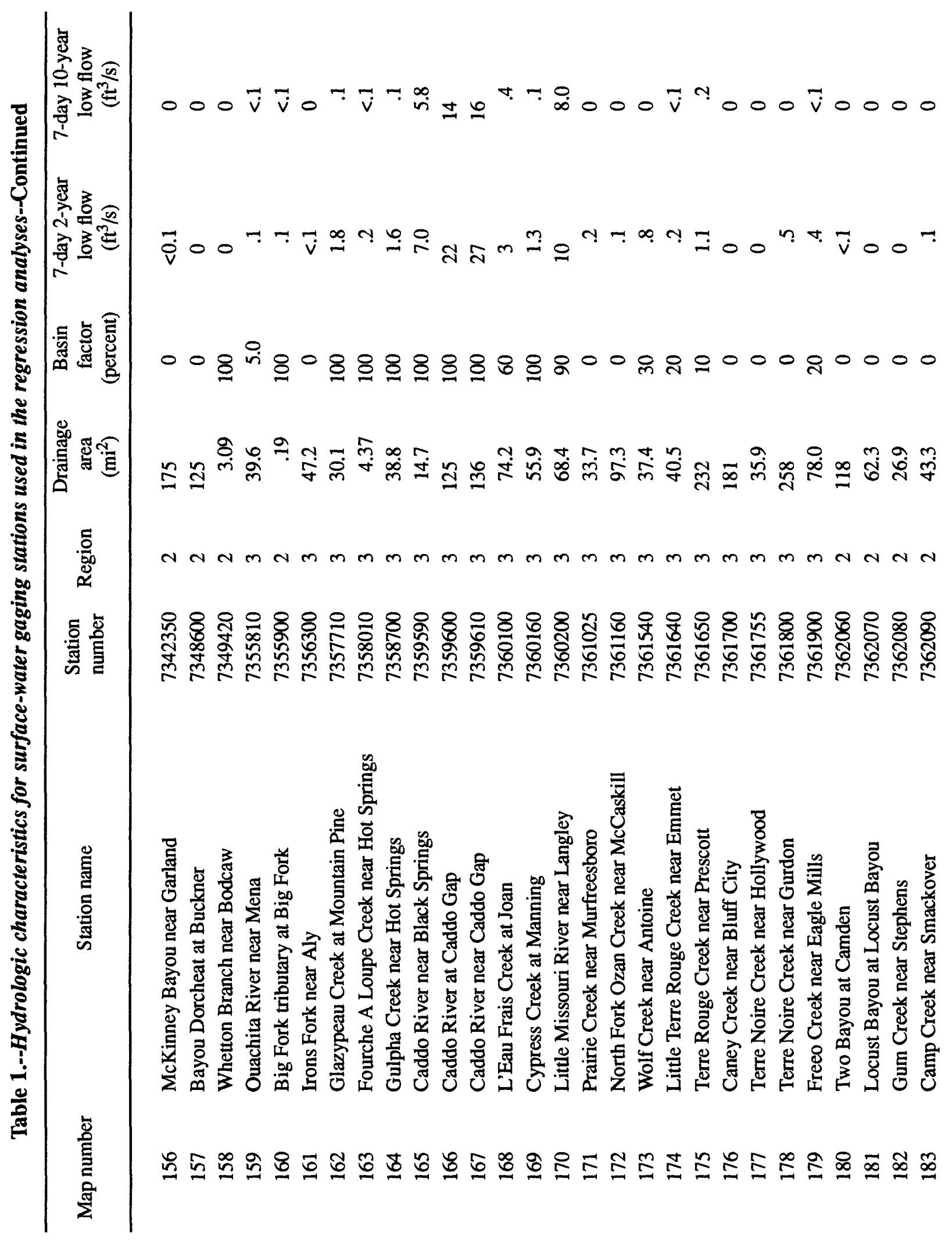




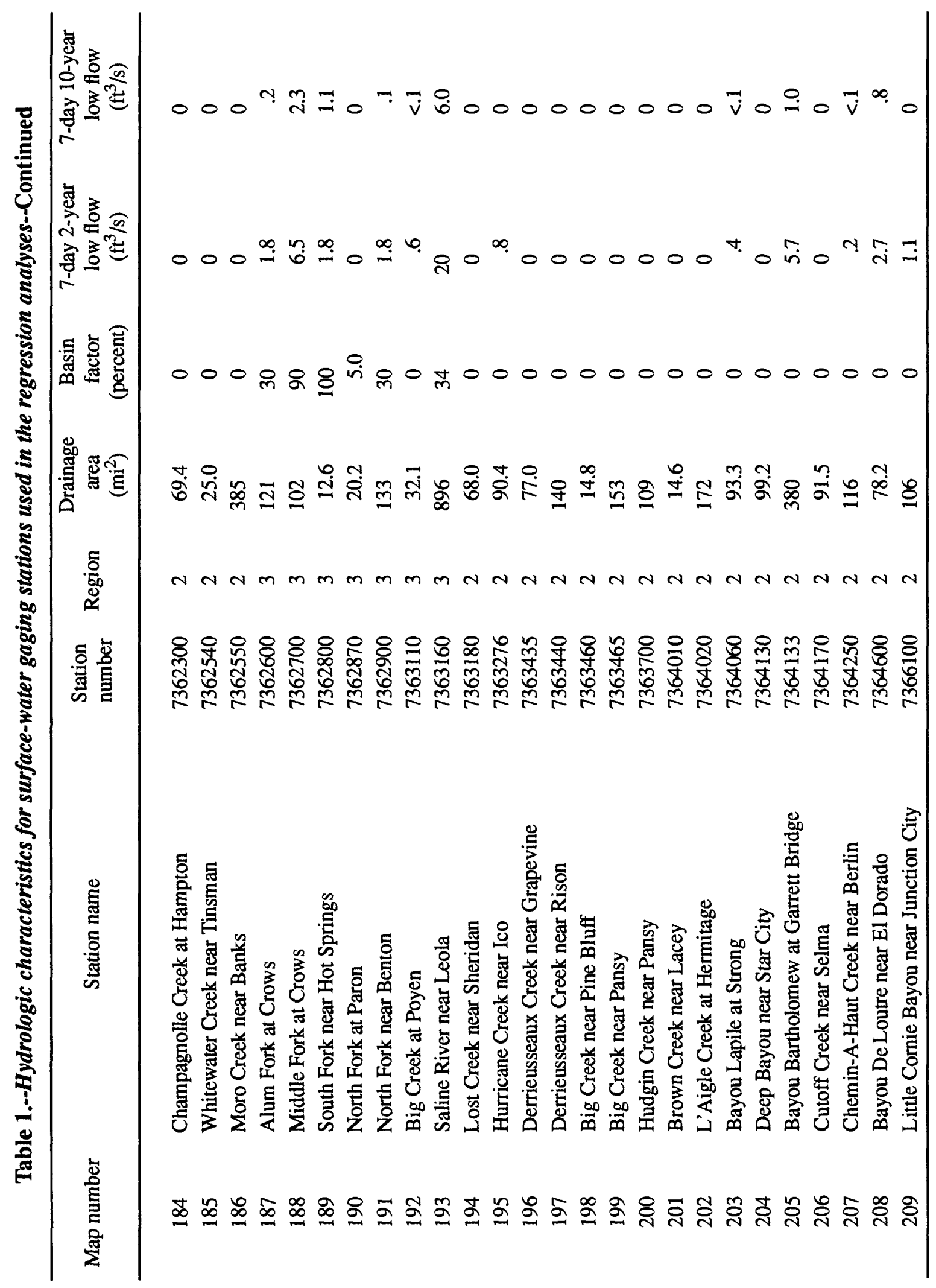




\section{Generalized Least Squares Regression to Estimate Low-Elow Statistics}

Low flow at a site may be characterized by an index of low flow such as the 7-day, 2-year or 7-day, 10-year low flow, which is the discharge having a 2-year or 10-year recurrence interval derived from a frequency curve of lowest average flow for 7 consecutive days in a year. To estimate the flow characteristics (the 7-day, 2-year or 10-year low flows) at a site with no flow records, a regional regression relation is developed to relate the flow characteristics to basin characteristics. After transformation of variables to logarithms, the regional regression model may be written as

$$
Y=X \beta+e,
$$

where $\mathrm{Y}$ is a $n x \mathbf{l}$ vector of transformed flow characteristics at $\mathrm{n}$ sites, $\mathrm{X}$ is an $n x p$ matrix of $(p-1)$ basin characteristics augmented by a column of 1 's, $\beta$ is a pxl vector of regression parameters to be estimated, and $\mathrm{e}$ is a $n x 1$ vector of errors. The data used to estimate the regression coefficients, $\beta$, are flow data collected at stream gages in the region and at partial-record sites where a number of base-flow measurements have been made and correlated with daily-mean discharge at a continuous-record site (Stedinger and Thomas, 1985; Ludwig, 1992). The data for this analysis are shown in table 1. Only the sites with nonzero flow characteristics were used because the regression models apply only to sites with nonzero flow characteristics. The logistic regression described earlier in this report is used to predict whether or not the site has a nonzero flow characteristic.

The accuracy of an estimated flow characteristic based on recorded or measured flows may vary greatly from site to site depending upon, among other things, the length of record at a gaged site or number of base-flow measurements at a partial-record site. Other factors that affect accuracy include natural variability of flow and degree of autocorrelation in annual minimum flows. Ordinary least squares regression is not appropriate when the response variable, in this case the low-flow characteristic, is not observed with equal accuracy at all sites used in the regression.

Stedinger and Tasker $(1985,1986)$ documented the value of an estimated generalized least squares (EGLS) regression procedure for regional regression of streamflow characteristics. The EGLS estimator of $\beta$ is

$$
\beta=\left(X^{T} \Lambda^{-1} X\right)^{-1} X^{T} \Lambda^{-1} Y,
$$

where it is assumed that the errors have zero mean $E[e]=0$, and covariance $E\left[e e^{T}\right]=\Lambda$.

The operational difficulty with this equation is that $\Lambda$ is unknown and must be estimated from the data at hand. Stedinger and Tasker (1985) proposed that $\Lambda$ be estimated as

$$
\Lambda=\gamma^{2} I+V,
$$

where $\gamma^{2}$ is an estimate of the model error variance due to an imperfect model, $\mathbf{I}$ is the identity matrix, and $\mathbf{V}$ is a $n \times n$ matrix of sampling covariances that depend on record length, natural variability of the flow characteristic, cross correlation of sample response variables, and which flow characteristic is being estimated. Thus, the EGLS procedure uses the $\Lambda$ matrix to assign different weights to observed flow characteristics based on their record length, cross correlation with flow characteristics at other sites and the model error variance, $\gamma^{2}$. Tasker and Stedinger (1989) provide further details on how the elements of $\Lambda$ are determined. The regression models are given in the sections on estimating the 7-day 2-year and 7-day 10-year low-flow values.

\section{PHYSICAL PROPERTIES THAT SIGNIFICANTLY AFFECT LOW-FLOW CHARACTERISTICS}

The low-flow characteristics of streams are directly related to the physical properties of the drainage basin. Drainage area (DA) is considered to be the predominant factor in explaining streamflow variability. Also, as suggested by Hines (1975), variations in low-flow yields can be closely associated with physiography. For example, drainage basins that are underlain by substrata that have high permeability and porosity almost always have greater base flows than do basins of equal size that are underlain by substrata with low permeability and porosity. Thus, when evaluating the variability of low flow, the type of bedrock underlying the drainage basin is also an important factor. Other factors such as soil type, forest cover, channel length, and slope that could potentially impact low-flow variability were found to be insignificant by comparison and were eliminated from the regionalization analyses. Therefore, drainage area and type of bedrock, herein represented by the term basin factor, are the only characteristics used in the regionalization of low-flow characteristics. The basin factor (BF) is defined as the percentage of drainage basin underlain by bedrock with high permeability. 
Drainage areas are available for all active and inactive continuous-record gaging stations and partial-record gaging stations. These data are included in a series of drainage-area reports (Sullavan and Terry, 1970; Sullavan, 1974; Hines and Yanchosek, 1978; and Yanchosek and Hines, 1979). Drainage areas for continuous-record gaging stations also are available upon request from the basin and streamflow characteristics file of the National Water Data Storage and Retrieval System (WATSTORE), a computerized data base maintained by the U.S. Geological Survey. Drainage areas for the gaging stations used in this study are given in table 1.

The division of the study area into regions based upon the observed association between physiography and lowflow yields is discussed in the following section. Table 1 gives the number of the region in which each station is located and the basin factor value associated with that station.

\section{LOW-FLOW DIVISIONS OF THE STATE}

An examination of the variability in low-flow characteristics determined for gaging stations in the study area indicates a close correlation to the water-yielding characteristics of the geologic formations that underlie a given drainage basin. The association between physiographic area and low-flow yields in the State was first suggested by Hines (1975). Similar patterns of sustained base flow also were noted by Hunrichs (1983) in a report showing perennial streams in the State. More recently, the relation between bedrock type and base flow was pointed out in a report by Ludwig (1992). For regionalization purposes therefore, these interpretations were used as the initial basis for subdividing the State into regions of well-sustained and poorly-sustained base flow (plate 1). This subdivision was further supported by the variation in the predictive equations that resulted from the application of the regression models in each region.

\section{Areas of Well-Sustained Base Flow}

Region 1 encompasses most of the upper White River drainage basin and parts of the Arkansas River basin in Arkansas. The region is defined physiographically by the Springfield and Salem Plateaus and includes all geologic units stratigraphically below the Boone Formation. The region is underlain by a series of limestone and dolomite units and, because of this, exhibits numerous collapse features that are characteristic of karst terrain. Streams in the region are sustained by discharges from numerous springs, which issue from an apparently well-developed system of solution channels. The well-sustained nature of the spring flow is indicative of a regional source of water that is supplemented during extended periods of precipitation by a local component of flow.

Region 3 lies in the southem Ouachita Mountains and extends southward into the unconsolidated Coastal Plain deposits. It includes much of the upper Ouachita River basin and parts of the Red River basin. Base flows within the Ouachita Mountain section primarily are derived from the Arkansas Novaculite and Bigfork Chert Formations, which are composed primarily of fine-grained sandstone and chert. The formations have been extensively folded and faulted resulting in a high secondary porosity and permeability which has enhanced the recharge potential of the rocks.

Within the Coastal Plain segment of Region 3, base flow is derived as rejected recharge from the more productive aquifers in the area including the Sparta Sand and the Nacatoch Sand. A substantial contribution to base flow in the Coastal Plain is also from alluvial terrace deposits that cap the upland, interstream areas. These deposits are remnants of older alluvial systems that once blanketed the area but have since been eroded by the present-day stream systems. The base-flow contribution of the terrace deposits varies from place to place depending on the permeability of the sediments that make up the terraces. The occurrence of terraces is not limited to the highly permeable areas shown in plate 1, but, based on the evaluation of streamflow records, terraces generally are not as productive elsewhere as indicated by the poorly-sustained area in Region 2 in southern Arkansas.

\section{Areas of Poorly-Sustained Base Flow}

Region 2 includes two separate areas that are geologically and physiographically different but are similar with respect to base flow. The northern part of region 2 includes the Boston Mountains, Arkansas Valley, and the northern part of the Ouachita Mountains physiographic provinces (fig. 1). The area is underlain by consolidated rocks consisting primarily of sandstone and shale. The primary porosity and permeability of these deposits have been destroyed by compaction and deep burial. Only limited amounts of ground water are available from secondary openings such as joints and fractures in the rocks. However, the fractures are not extensive enough to supply the base flows of streams. Most streams in this area recede to zero flow each year. 
The southern part of region 2 lies in the West Gulf Coastal Plain physiographic province. The area is underlain by unconsolidated deposits composed of sand, silt, and clay. The streams in the area, which encompasses much of south-central Arkansas, generally do not have sustained base flow because in part the stream channels are not incised deeply enough to intercept the water table and, in part, because the surficial deposits have low permeability and porosity.

\section{PREDICTIVE EQUATIONS FOR ESTIMATING LOW-FLOW CHARACTERISTICS}

The regression models described earlier in this report were applied in each of the three regions in the study area. The models were calibrated using the known data for stream gaging stations given in table 1 . Predictive equations resulting from the calibrated models can be used to estimate selected low-flow characteristics at ungaged sites in each region.

Low-flow characteristics $Q_{7,2}$ and $Q_{7,10}$ can be estimated at ungaged sites by the following three-step method. The first step is to estimate the probability that the 7-day annual minimum flow is zero (PRZERO) at the ungaged site of interest by the method explained in the following section. The second step uses the estimated probability of zero flow, PRZERO, to determine if the estimated value of $Q_{7,2}$ or $Q_{7,10}$ is zero or needs to be estimated from one of the regional equations.

\section{Estimating Probability of Zero Flow at an Ungaged Site}

To estimate the probability (PRZERO) of the 7-day annual minimum flow being zero for an arbitrary year at an ungaged site, determine (1) the drainage area in square miles, DA, above the site, (2) the region $(1,2$, or 3$)$ in which the site is located, and (3) the percentage of the basin drainage area, BF, that is in the sustained base flow areas indicated on the map in plate 1. PRZERO is computed as follows:

$$
\text { PRZERO }=1-\{\exp (P) /[1+\exp (P)]\},
$$

where, if the site in question is in region 1 or 3 ,

$$
P=1.34+0.00163(D A)+0.0228(B F) \text {, }
$$

or, if the site in question is in region 2 ,

$$
P=-0.144+0.0041(D A)
$$

\section{Estimating Seven-Dav Two-Year Low-Flow Values}

If the value for PRZERO from the above equation is greater than 0.5 , that is, there is a greater than 50 percent chance that the flow at the desired location is zero, then $Q_{7,2}$ is estimated to be zero. However, if PRZERO is estimated to be less than or equal to 0.5 , then $\mathrm{Q}_{7,2}$ can be estimated from one of the regional equations below. For a site in region 1 , the equation is:

$$
Q_{7,2}=0.021(D A)^{0.554}(B F+1)^{0.713}
$$

For a site in region 2 , the equation is:

$$
Q_{7,2}=0.0025(D A)^{0.977}
$$

For a site in region 3 , the equation is:

$$
Q_{7,2}=0.0053(D A)^{0.740}(B F+1)^{0.795}
$$




\section{Estimating Seven-Day Ten-Year Low-Elow Values}

If PRZERO is estimated to be greater than 0.1 , that is there is a greater than 90 percent chance that the flow is zero, then $Q_{7,10}$ is estimated to be zero. However, if PRZERO is estimated to be less than or equal to 0.1, then $Q_{7,10}$ can be estimated from one of the regional equations below. For a site in region 1, the equation is:

$$
Q_{7,10}=0.0031(D A)^{0.58}(B F+1)^{0.915}
$$

For a site in region 2 , the equation is:

$$
Q_{7,10}=0.0010(D A)^{0.986}
$$

For a site in region 3 , the equation is:

$$
Q_{7,10}=0.00049(D A)^{0.768}(B F+1)^{1.104}
$$

\section{UNCERTAINTY AND LIMITATIONS OF PREDICTIVE EQUATIONS}

\section{Prediction Interval Estimates}

The regional regression analysis not only provides predictive equations for estimating $Q_{7,2}$ and $Q_{7,10}$, but can also provide an estimate of the uncertainty associated with the estimate. One measure of uncertainty is the prediction interval of an estimate at an ungaged site. A $100(1-\alpha)$ prediction interval for the true low-flow characteristic, $\theta_{7, \tau}$, at an ungaged site can be computed by

$$
(1 / T) Q, .<\theta_{7},<(T) Q_{7},
$$

where the value of $\mathrm{T}$ can be computed for each of the six regional estimating equations in the previous section by the following method.

Let $\mathbf{x}_{\mathbf{i}}$ represent a row vector of logarithms of basin characteristics at ungaged site $i$ augmented by 1 . For example, for a site with $\mathrm{DA}=50 \mathrm{mi}^{2}$ and $\mathrm{BF}=15$ percent,

$$
x_{i}=\left[1, \log _{10}(50), \log _{10}(15+1)\right] \text {. }
$$

Then the standard error of prediction at site $i$, in $\log$ units, would be given by:

$$
S_{i}=\left[\gamma^{2}+x_{i} U x_{i}^{\prime}\right]^{0.5},
$$

where $\gamma^{2}$ and $\mathbf{U}$ are the model error variance and the covariance matrix for the regression coefficients, respectively,

associated with the estimating equation, and

$\mathbf{x}_{\mathbf{i}}{ }^{\prime}$ is the transpose of $\mathbf{x}_{\mathbf{i}}$. The value for $T$ is then calculated by

$$
\log _{10}(T)=t_{(\alpha / 2, n-p)} S_{i},
$$

where $t_{(\alpha / 2, n-p)}$ is the critical value of the $t$-distribution for $n-p$ degrees of freedom and is tabulated in many

statistical texts, $\mathrm{n}$ is the number of observations used in the regression analysis, and

$\mathrm{p}$ is the number of basin characteristics (explanatory variables) used in the regression plus one.

The values for $\gamma^{2}, \mathbf{U}, \mathrm{n}$, and $\mathrm{p}$ are given in table 2 for each of the six regional predictive equations.

\section{Limitations of Predictive Equations}

The observed data used to calibrate the regression models were collected at sites with drainage basin areas ranging from 3.2 to $829 \mathrm{mi}^{2}$ in region $1,3.3$ to $764 \mathrm{mi}^{2}$ in region 2 , and 0.19 to $896 \mathrm{mi}^{2}$ in region 3 . The resulting predictions could have errors much larger than those estimated from the observed data for basins whose size falls outside these ranges. If the uncertainty in the predictions, as measured by the prediction interval, is too great for an intended use, an improved estimate at a site can be made by making several low-flow discharge measurements at the site on different base flow recessions and correlating these flow data with concurrent flow data at a nearby gaging station. 
Table 2.--Values needed to calculate confidence intervals

[ $\mathrm{n}$ is the number of sites used in the regression, $\mathrm{p}$ is the number of regression coefficients estimated (including the regression constant), $t$ is the critical value to the $t$-distribution used to calculate 90 percent prediction intervals, $\gamma$ is the model standard error, in log units, and $U$ is the $(p \times p)$ covariance matrix of the regression coefficients]

\begin{tabular}{|c|c|c|c|c|c|c|c|c|}
\hline $\begin{array}{c}\text { Equation } \\
\text { number }\end{array}$ & $\begin{array}{l}\text { Dependent } \\
\text { variable }\end{array}$ & $\mathbf{n}$ & p & $\mathrm{t}$ & $\gamma$ & \multicolumn{3}{|c|}{$\mathrm{U}$} \\
\hline \multicolumn{9}{|c|}{ Region 1} \\
\hline \multirow[t]{3}{*}{1} & $\mathrm{Q}_{7,2}$ & 57 & 3 & 1.68 & 0.502 & 0.16798 & -0.05657 & -0.02418 \\
\hline & & & & & & -.05657 & .02808 & -.00095 \\
\hline & & & & & & -.02418 & -.00095 & .01480 \\
\hline \multirow[t]{4}{*}{4} & $\mathrm{Q}_{7,10}$ & 53 & 3 & 1.68 & .615 & .32825 & -.09237 & -.06919 \\
\hline & & & & & & -.09237 & .04426 & .00044 \\
\hline & & & & & & -.06919 & .00044 & .03788 \\
\hline & & & & & Region 2 & & & \\
\hline \multirow[t]{2}{*}{2} & $\mathrm{Q}_{7,2}$ & 71 & 2 & 1.67 & .487 & .15957 & -.06666 & \\
\hline & & & & & & -.06666 & .02991 & \\
\hline \multirow[t]{2}{*}{5} & $\mathrm{Q}_{7,10}$ & 12 & 2 & 1.81 & .290 & 1.5718 & -.5784 & \\
\hline & & & & & & -.5784 & .2166 & \\
\hline \multicolumn{9}{|c|}{ Region 3} \\
\hline \multirow[t]{2}{*}{3} & $\mathrm{Q}_{7,2}$ & 86 & 3 & 1.66 & .476 & .15280 & -.02815 & -.04715 \\
\hline & & & & & & -.02815 & .01108 & .00315 \\
\hline \multirow[t]{4}{*}{6} & $Q_{7,10}$ & 75 & 3 & 1.67 & .639 & -.04715 & .00315 & .02108 \\
\hline & & & & & & .32321 & -.05416 & -.10868 \\
\hline & & & & & & -.05416 & .02106 & .00656 \\
\hline & & & & & & -.10868 & .00656 & .05071 \\
\hline
\end{tabular}




\section{Fit of Data to the Generalized Least Squares Regression Model}

One measure of the fit of observed data to the model is the proportion of total variance in the observed flow value that is explained by the model, $\mathrm{R}^{2}$. This value is calculated as:

$$
R^{2}=\left(\text { Variance of } y-\gamma^{2}\right) /(\text { Variance of } y)
$$

in which $y$ is the log transformed low flow and $\gamma$ is the estimated model standard error given in table 2 . The values of $\mathrm{R}^{2}$ for each of the predictive equations are as follows:

For Region 1: Equation 1, $\mathrm{R}^{2}=0.50$

$$
\text { Equation } 4, R^{2}=0.41
$$

For Region 2: Equation 2, $\mathrm{R}^{2}=0.44$

Equation $5, \mathrm{R}^{2}=0.75$

For Region 3: Equation $3, R^{2}=0.61$

Equation $5, R^{2}=0.47$

\section{EXAMPLE COMPUTATIONS}

Suppose estimates of $Q_{7,2}$ and $Q_{7,10}$ are needed for an ungaged site in region 1 with $D A=50 \mathrm{mi}^{2}$ and $B F=15$ percent. The first step is to calculate PRZERO. In this case:

$$
P=1.34+0.00163(50)+0.0228(15)=1.7635
$$

and

$$
\text { PRZERO }=1-\{\exp (1.764) /[1+\exp (1.764)]\}=0.15
$$

Since PRZERO is less than $0.5, \mathrm{Q}_{7,2}$ is estimated by equation 1 ,

$$
Q_{7,2}=0.021(50)^{0.554}(15+1)^{0.713}=1.32 \mathrm{ft} / \mathrm{s} \text {. }
$$

Ninety percent prediction interval estimates can be made as follows:

From table $2, \gamma^{2}=0.502^{2}=0.252$, and $t=1.68$.

The vector of basin characteristics is $\mathbf{x}_{\mathbf{i}}=\left[1, \log _{10}(50), \log _{10}(15+1)\right]$, and the $3 \times 3$ matrix $\mathbf{U}$ is:

$$
\begin{aligned}
& \mathbf{U}=\begin{array}{rrr}
0.16798 & -0.05657 & -0.02418 \\
-0.05657 & 0.02808 & -0.00095 \\
-0.02418 & -0.00095 & 0.01480
\end{array} \\
& S_{i}=\left[\gamma^{2}+x_{i} U x_{i}\right]^{0.5}=[0.252+0.0162]^{0.5}=0.518 \text {, and } T=10^{0.518(1.68)}=7.42 \text {. }
\end{aligned}
$$

Therefore, an approximate 90 percent prediction interval is $1.32 / 7.42<\theta_{7,2}<1.32(7.42)$ or $(0.2,9.8)$. This indicates that there is a 90 percent chance that the unknown discharge $\left(Q_{7,2}\right.$ in this case) is within the range of 0.2 and 9.8 $\mathrm{ft}^{3} / \mathrm{s}$. Since PRZERO is greater than $0.1, \mathrm{Q}_{7,10}$ is estimated to be zero.

\section{EXTRAPOLATION OF LOW-FLOW DATA}

Regional flow equations presented herein can be used to estimate low-flow characteristics at any desired site on streams in the study area. However, it is commonly desirable to estimate the characteristics at an ungaged site that is on a stream where low-flow characteristics are known at a nearby continuous-record or partial-record gaging station. Within limits, the low-flow characteristics can be transferred from a gaged site either upstream or downstream, to an ungaged site using a proration by drainage areas. The relation is defined as follows:

$$
7 Q T, u=7 Q, g\left(\frac{A u}{A g}\right)
$$


where, $Q_{7, T}$ is average minimum 7-consecutive day discharge for a $T$-year recurrence interval (cubic feet per second), $\mathbf{u}$ is ungaged site where low-flow values are to be determined,

$\mathrm{g}$ is gaged site where low-flow values are know, and

$A$ is drainage area (square miles).

Limitations pertaining to the use of the relation include the following: (1) the drainage area of the ungaged site must be less than 50 percent greater or smaller than the drainage area of the gaged site, and (2) the extrapolation of the low-flow characteristics should not be extended beyond the confluence of a major tributary stream. A major tributary stream is defined herein as any stream that causes the drainage area of the gaged stream to change more than 25 percent at the confluence.

\section{PERSONAL COMPUTER SOFTWARE FOR COMPUTING LOW-FLOW CHARACTERISTICS}

A FORTRAN computer program has been written to perform the rather tedious computations. A disk containing the program is included at the end of this report (in pocket). The program is compatible with the MS DOS ${ }^{1}$ operating system which is available on many personal computers. The program is activated by typing "ARK" after inserting the disk into the proper disk drive. The user is asked to input the region $(1,2$, or 3$)$ from plate 1 , the drainage area (DA), and the basin factor (BF) of the site of interest. The program is driven by queries and prompts and requires no other user documentation. The source code for the program is given in Appendix 1.

\section{SUMMARY}

Regression analysis was selected as the methodology for regionalizing low-flow characteristics in the study area. Suggestions made by earlier investigators, later supported by the performance of the regression models, led to the division of the study area into three regions based upon physiography. Data collected at stream-gaging stations in two of the regions reflect well sustained base flows. Conversely, data collected at stream-gaging stations in the third reflect poorly sustained base flow. Much of the area in the former two regions is underlain by substrata that readily yield water to streams. Substrata underlying the latter region yields relatively little water to streams. In drainage basins underlain by substrata that readily yield water, Basin Factor, was a significant independent variable in the regression models. Drainage area was a significant independent variable in the regression models for all three regions.

A logistic regression model and a generalized least squares regression model were calibrated for each region. The calibration of the logistic regression model yielded predictive equations that can be used to estimate the probability that the 7-day annual mean flow at an ungaged site is zero. Calibration of the generalized least squares model in each region resulted in predictive equations that can be used to estimate the 7-day 2-year and the 7-day 10-year low flows at ungaged sites. In each region, if the probability of zero flow is greater than 0.5 , then the $Q_{7,2}$ is estimated to be zero. If it is less than or equal to 0.5 , then the estimated $Q_{7,2}$ should be computed by the appropriate predictive equation for that region. Further, if the probability of zero flow is greater than 0.1 at an ungaged site, then the $Q_{7,10}$ should be estimated to be zero. However, if it is less than or equal to 0.1 then the estimated $Q_{7,10}$ should be computed by the appropriate predictive equation for that region.

An interactive FORTRAN computer program was written to solve the predictive equations using values for the independent variables input by the user. This program is provided on a personal computer diskette and in printed form as a part of this report.

${ }^{1}$ Use of brand name in this report is for identification purposes only and does not constitute endorsement by the U.S. Geological Survey. 


\section{REFERENCES CITED}

Hines, M.S., 1965, Water-supply characteristics of selected Arkansas streams: Arkansas Geological Commission Water Resources Circular 9, 43 p.

-.-- 1975, Flow-duration and low-flow frequency determinations of selected Arkansas streams: Arkansas Geological Commission Water Resources Circular 12,75 p.

Hines, M.S., and Yanchosek, J.J., 1978, Drainage areas of streams in Arkansas, Red River basin: U.S. Geological Survey Open-File Report 78-555, 42 p.

Hunrichs, R.A., 1983, Identification and classification of perennial streams of Arkansas: U.S. Geological Survey Water-Resources Investigations Report 83-4063, 1 sheet, scale 1:500,000.

Ludwig, A.H., 1992, Flow duration and low-flow characteristics of selected Arkansas streams: U.S. Geological Survey Water-Resources Investigations Report 92-4026, $57 \mathrm{p}$.

Neely, B.L., Jr., 1987, Magnitude and frequency of floods in Arkansas: U.S. Geological Survey Water-Resources Investigations Report $86-4335,51 \mathrm{p}$.

Patterson, J.L., 1968, Storage requirements for Arkansas streams: U.S. Geological Survey Water-Supply Paper 1859G, $35 \mathrm{p}$.

-...- 1971, Floods in Arkansas, magnitude and frequency characteristics through 1968: Arkansas Geological Commission Water Resources Circular 11, 197 p.

Stedinger, J.R., and Tasker, G.D., 1985, Regional hydrologic analysis 1: Water Resources Research, v. 21, no. 9 , p. 1421-1432.

-.-- 1986, Regional hydrologic analysis 2: Water Resources Research, v. 22, no. 10, p. 1487-1499.

Stedinger, J.R., and Thomas, W.O., 1985, Low-flow frequency estimation using base flow measurements: U.S. Geological Survey Open-File Report 85-95, 22 p.

Sullavan, J.N., 1974, Drainage areas of streams in Arkansas, White River basin: U.S. Geological Survey open-file report, $123 \mathrm{p}$.

Sullavan, J.N., and Terry, J.E., 1970, Drainage area of streams in Arkansas, Arkansas River basin: U.S. Geological Survey open-file report, $75 \mathrm{p}$.

Tasker, G.D., 1989, Regionalization of low flow characteristics using logistic and GLS regression in Kavvas, M.L., ed., New Directions for Surface Water Modeling, IAHS Publication No. 181, p. 323-331.

Tasker, G.D., and Stedinger, J.R., 1989, An operational GLS model for hydrologic regression: Journal of Hydrology, v. iii, p. 361-375.

Yanchosek, J.J., and Hines, M.S., 1979, Drainage areas of streams in Arkansas, Ouachita River basin: U.S. Geological Survey open-file report, $87 \mathrm{p}$. 


\section{APPENDIX}

PROGRAM LISTING FOR COMPUTATION OF REGIONAL

LOW-FLOW VALUES 


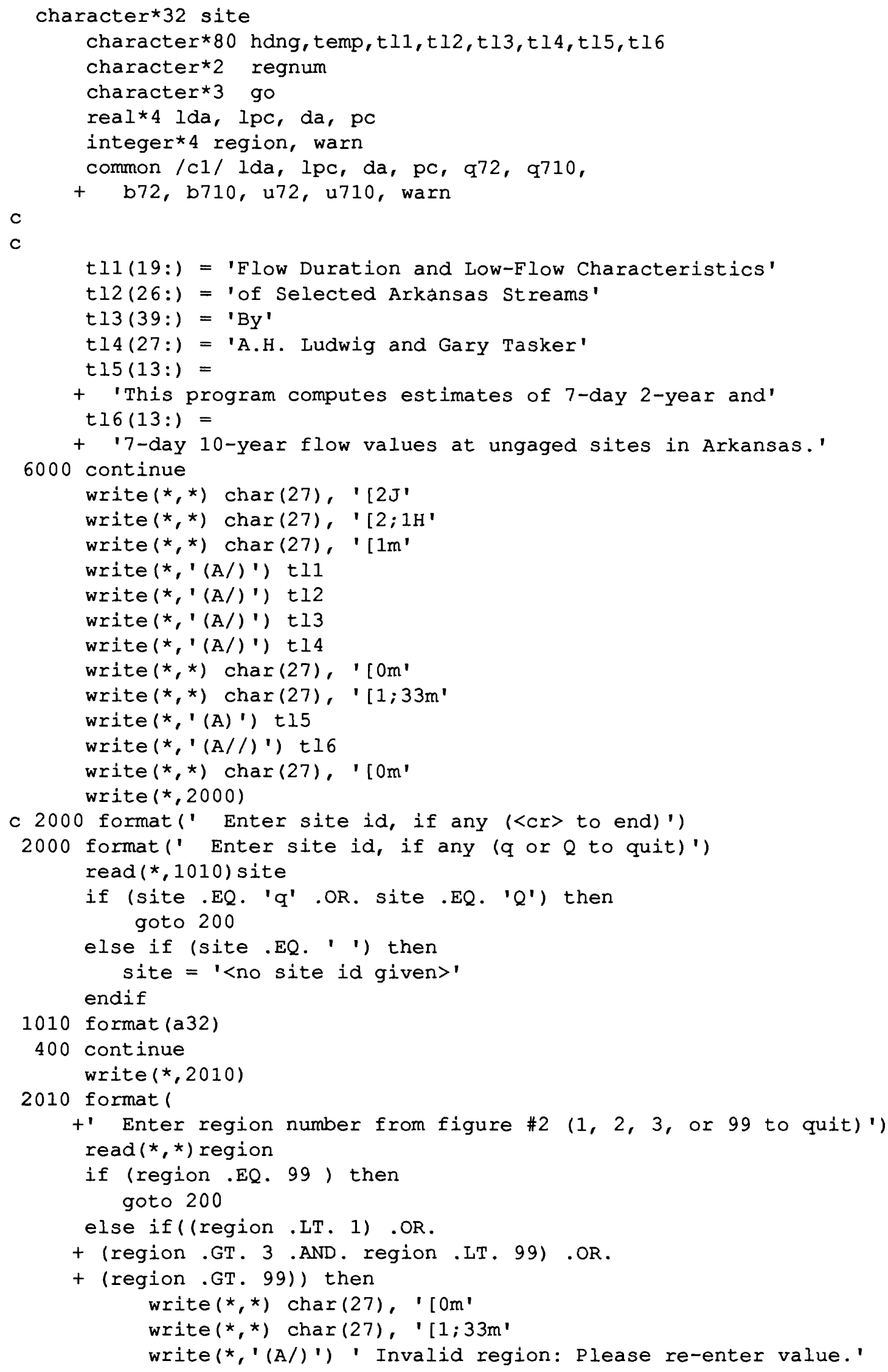




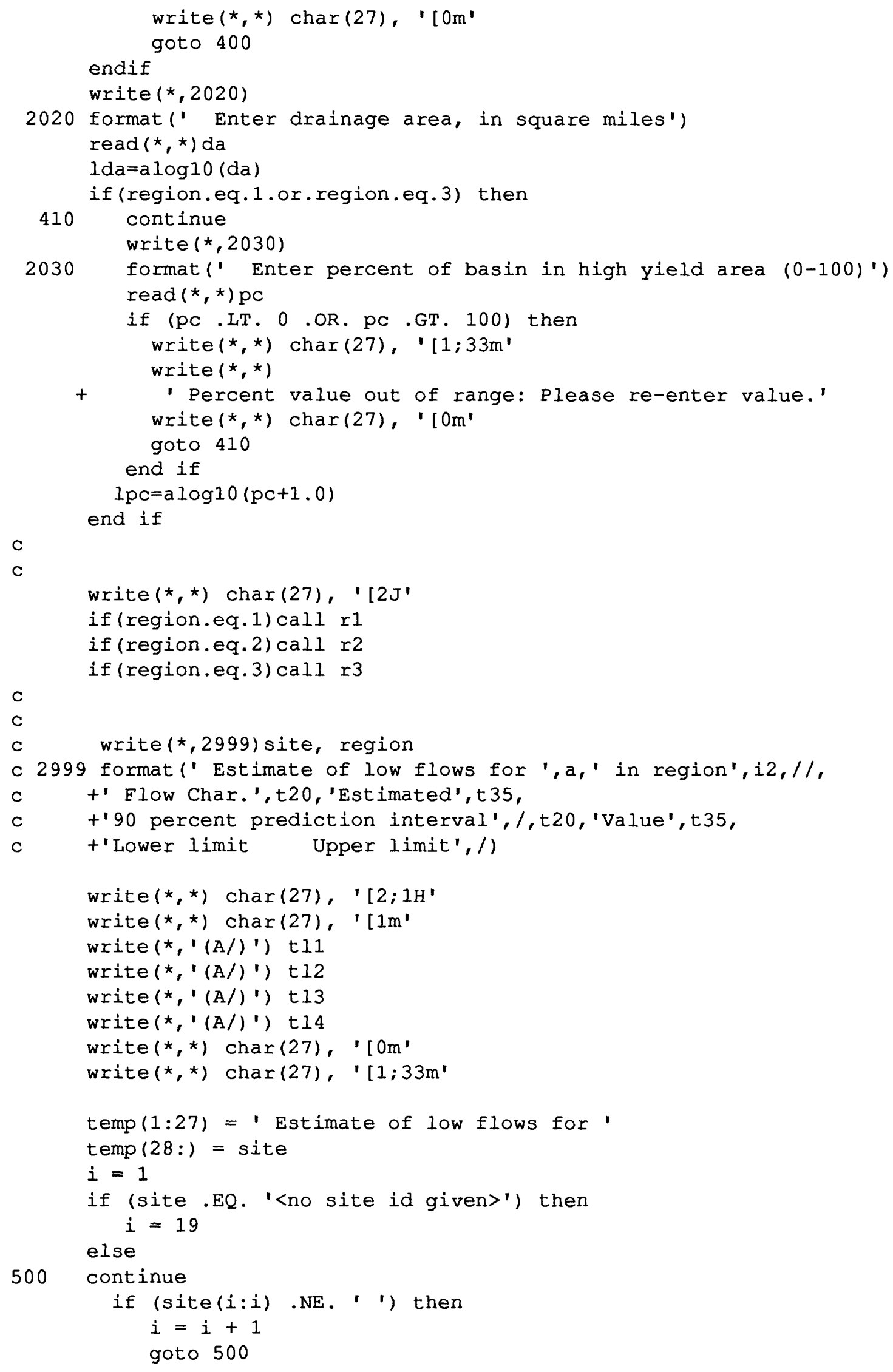




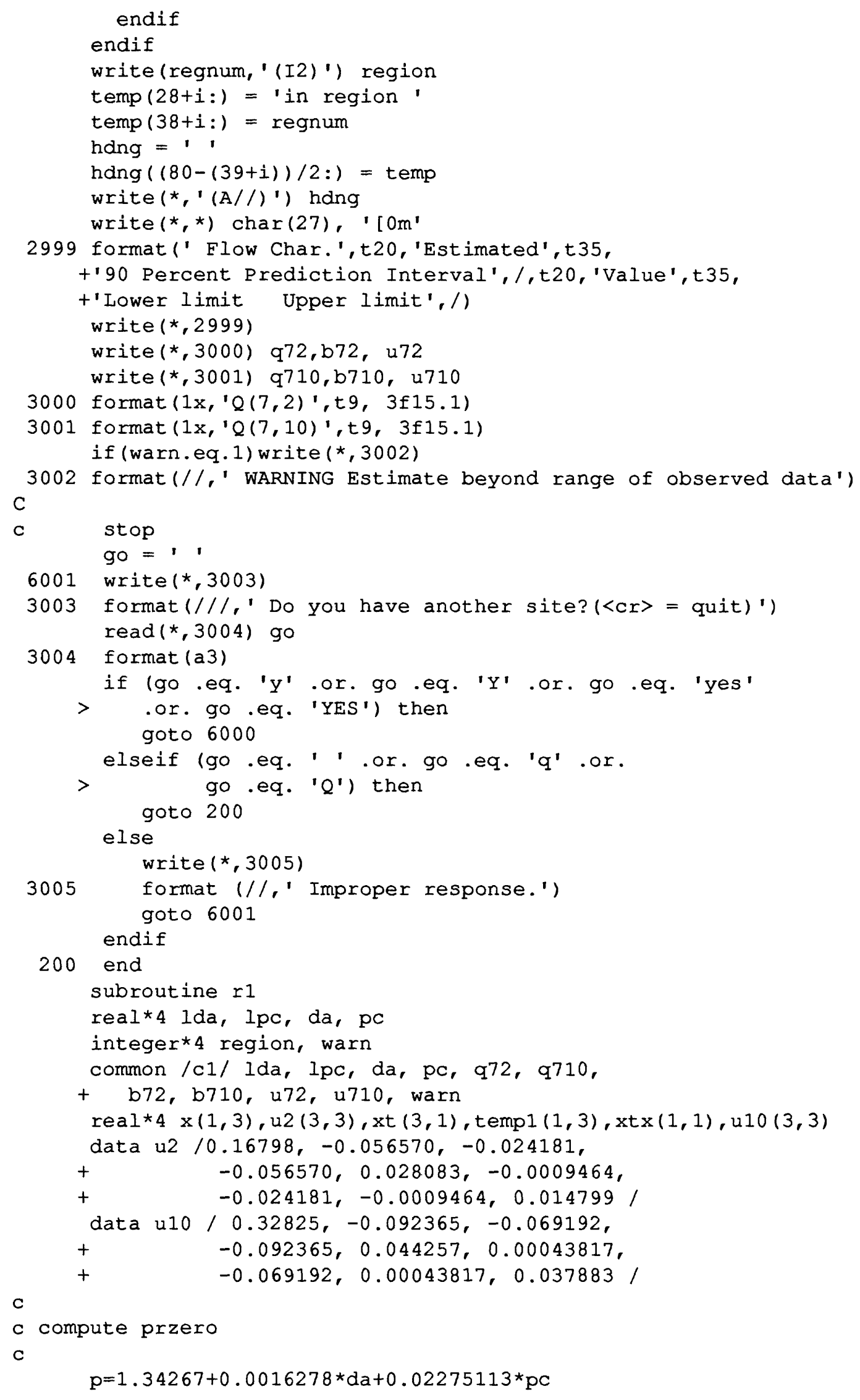




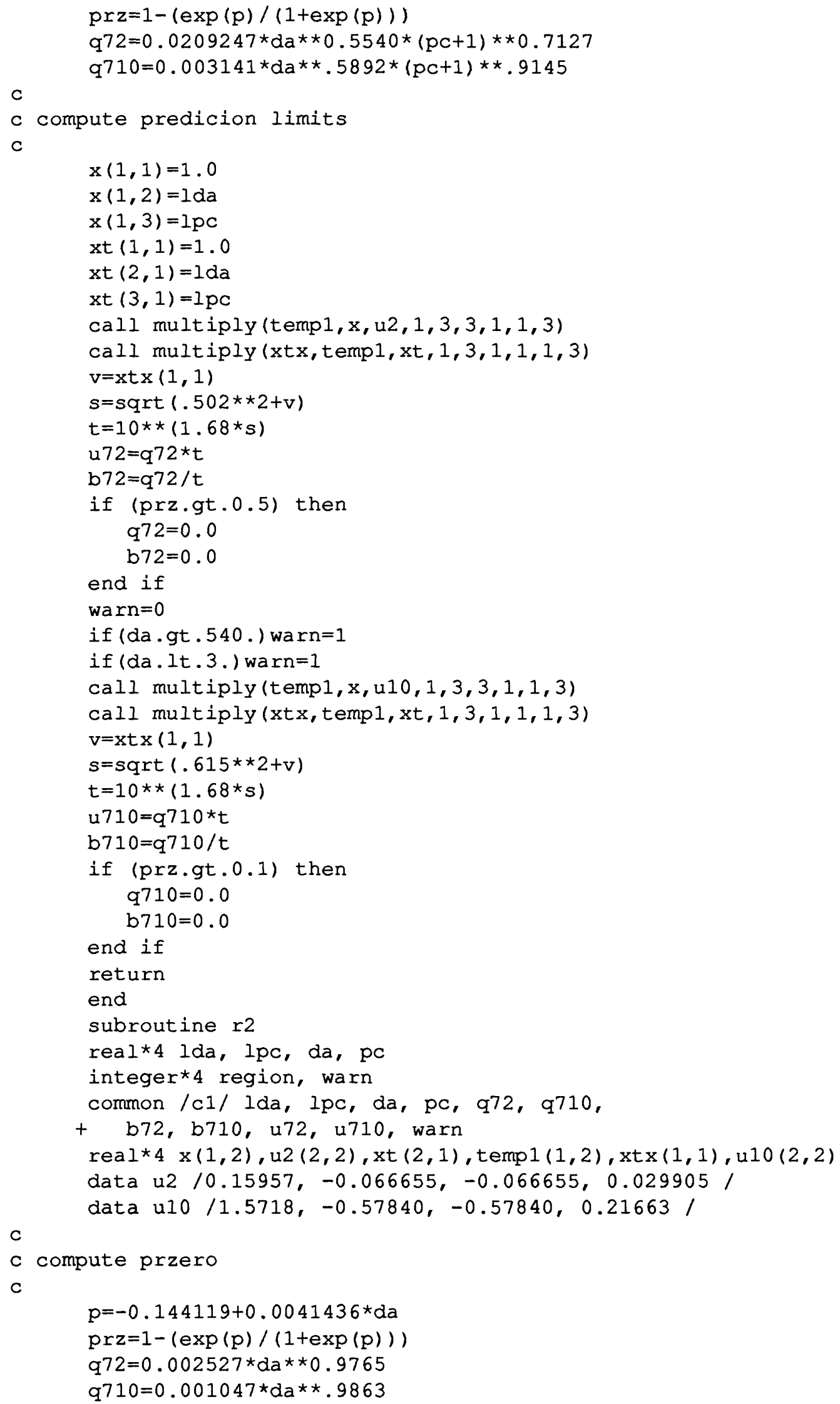


c

c compute predicion limits

c

$x(1,1)=1.0$
$x(1,2)=1$ da

$\mathrm{xt}(1,1)=1.0$

$x t(2,1)=1 d a$

call multiply (temp1, x, u2, 1, 2, 2, 1, 1, 2)

call multiply (xtx, temp1, xt, $1,2,1,1,1,2$ )

$\mathrm{v}=\mathrm{xt} \mathrm{x}(1,1)$

$s=\operatorname{sqrt}(.487 * * 2+v)$

$t=10 * *(1.67 * s)$

$\mathrm{u} 72=\mathrm{q} 72 * \mathrm{t}$

$\mathrm{b} 72=\mathrm{q} 72 / \mathrm{t}$

if (prz.gt.0.5) then

$\mathrm{q} 72=0.0$

b72 $=0.0$

end if

warn $=0$

if (da.gt . 570.) warn=1

if (da. . . . .2) warn=1

call multiply (temp1, $x, u 10,1,2,2,1,1,2$ )

call multiply (xtx, templ, $x t, 1,2,1,1,1,2$ )

$v=x t x(1,1)$

$s=\operatorname{sqrt}(.290 * \star 2+v)$

$t=10 * *(1.81 * s)$

$\mathrm{u} 710=\mathrm{q} 710 * \mathrm{t}$

b710=q710/t

if (prz.gt.0.1) then

$\mathrm{q} 710=0.0$

b710 $=0.0$

end if

return

end

subroutine $r 3$

real*4 lda, lpc, da, pc

integer* 4 region, warn

common /c1/ lda, lpc, da, pc, q72, q710,

$+\mathrm{b} 72$, b710, u72, u710, warn

$\operatorname{real} * 4 \mathrm{x}(1,3), \mathrm{u} 2(3,3), \mathrm{xt}(3,1), \operatorname{temp} 1(1,3), \mathrm{xtx}(1,1), \mathrm{u} 10(3,3)$

data u2 / $0.15280,-0.028150,-0.047149$,

$+\quad-0.028150,0.011081,0.0031482$,

$+\quad-0.047149,0.0031482,0.021081 /$

data u10/0.32321, $-0.054161,-0.10868$,

$+\quad-0.054161,0.021063,0.0065608$,

$+\quad-0.10868,0.0065608,0.050705 /$

c

C compute przero

c

$p=1.34267+0.0016278 * d a+0.02275113 * p c$

$\operatorname{prz}=1-(\exp (\mathrm{p}) /(1+\exp (\mathrm{p})))$

$q 72=0.005324 * d a * * 0.7401 *(p c+1) * * 0.7951$

$q 710=0.000489 * d a * * .7682 *(p c+1) * * 1.1041$

C 
C

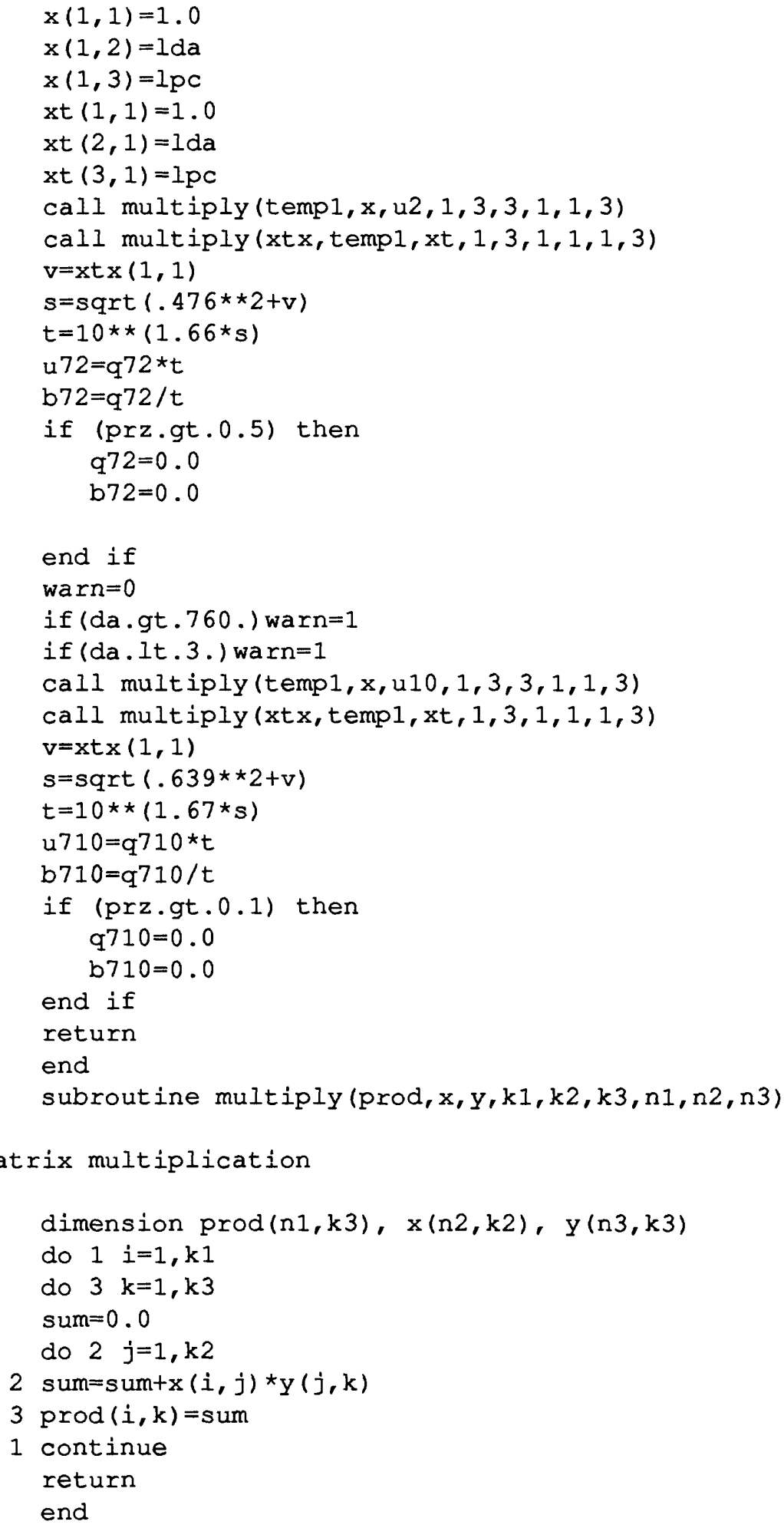

